\title{
PARACOCCIDIOIDOMYCOSIS IN JAPAN
}

\author{
REPORT OF A CASE
}

\begin{abstract}
Taishiro CHIKAMORI (1), Satoshi SAKa (1), Hiroshi NAGaNo (1), Shigeru SAEKI (2), Carlos da Silva LAGaZ (3), Maria Conceição RODRIGUES (3), Gintia Marzagão CaSSAGUERRA (3) and Maria Luisa BRACCIALLI (3)
\end{abstract}

\section{S U M M A R Y}

The Authors report a non-autochthonous case of paracoccidioidomycosis in Tokyo, the second related in Japan. The patient lived for nearly five years in the urban area of São Paulo, where probably she acquired the primary infection. There was no history of corticoid therapy or other diseases that could explain paracoccidioidomycosis. Three years after her return to Japan, she presented lymphadenopathy, hepatosplenic involvement and absence of pulmonary lesions. The present case, with histopathological examination and culture positive to Paracoccidioides brasiliensis also showed compatible serological results. The blastic feature of bone lesions, rare in ribs in this mycosis, as well as the generalized lymphadenopathy are discussed. Treatment with amphotericin B and ketoconazole offered good results. In this paper the Authors discuss the problem of the "pathology of importation" with its implications.

\section{N T R O D U G T I O N}

The pathology of importation also named "exotic pathology" establishes an important actual problem. LACAZ et al. 4 report some cases of paracoccidioidomycosis that have been related in the United States of America, Asia and Africa and they were not autochthonous. In such cases, the patients lived in endemic areas and presented the disease many years after. The interference of the factor age acting with the thymodependent system, as well as the iatropharmocogeny and associated diseases compose some of the noted factors to explain the awakening of latent processes, that is, the primary infection.

The intensive aerial and maritime traffic: set the physicians of surnamed developed countries in acquaintance with this type of pathology. Tables I and II in this paper, extracted from the papers of GREER \& RESTREPO 1,2 show some non-autochthonous cases of paracoccidioidomycosis, respectively in the United States of America, Europe, Asia and Africa.

In this paper the Authors report the second case of paracoccidioidomycosis observed in Japan, in a woman that lived for nearly five years in São Paulo.

\section{Report of case. Clinical aspects and evolution}

H. M., 34-year-old woman was admitted to the St. Luke's International Hospital in February 24,1983 , with fever and cervical lymphnodes adenopathy, as well as in periaortic region and hepatic hilus. The patient had been well three months before the admission, when she noticed right cervical lymphnode swelling without ten-

(1) Department of Internal Medicine of St. Luke's International Hospital

(2) Department of Pathology of St. Luke's International Hospital

(3) Instituto de Medicina Tropical àe São Paulo and Laboratório de Micologia Médica (LIM - 53 HCFMUSP) 
CHIKAMORI, T.; SAKA, S.; NAGANO, H.; SAEKI, S.; LACAZ, C. da S.; RODRIGUES, M. C.; CASSAGUERRA, C. M. \& BRACCIALLI, M. L. - Paracoccidlioidomycosis in Japan. Report of a case. Rev. Inst. Med. trop. São Paulo 26: 267-271, 1984 .

T A B L E I

U.S. documented non-autochthonous cases (Greer \& Restrepo ${ }^{1,2}$ )

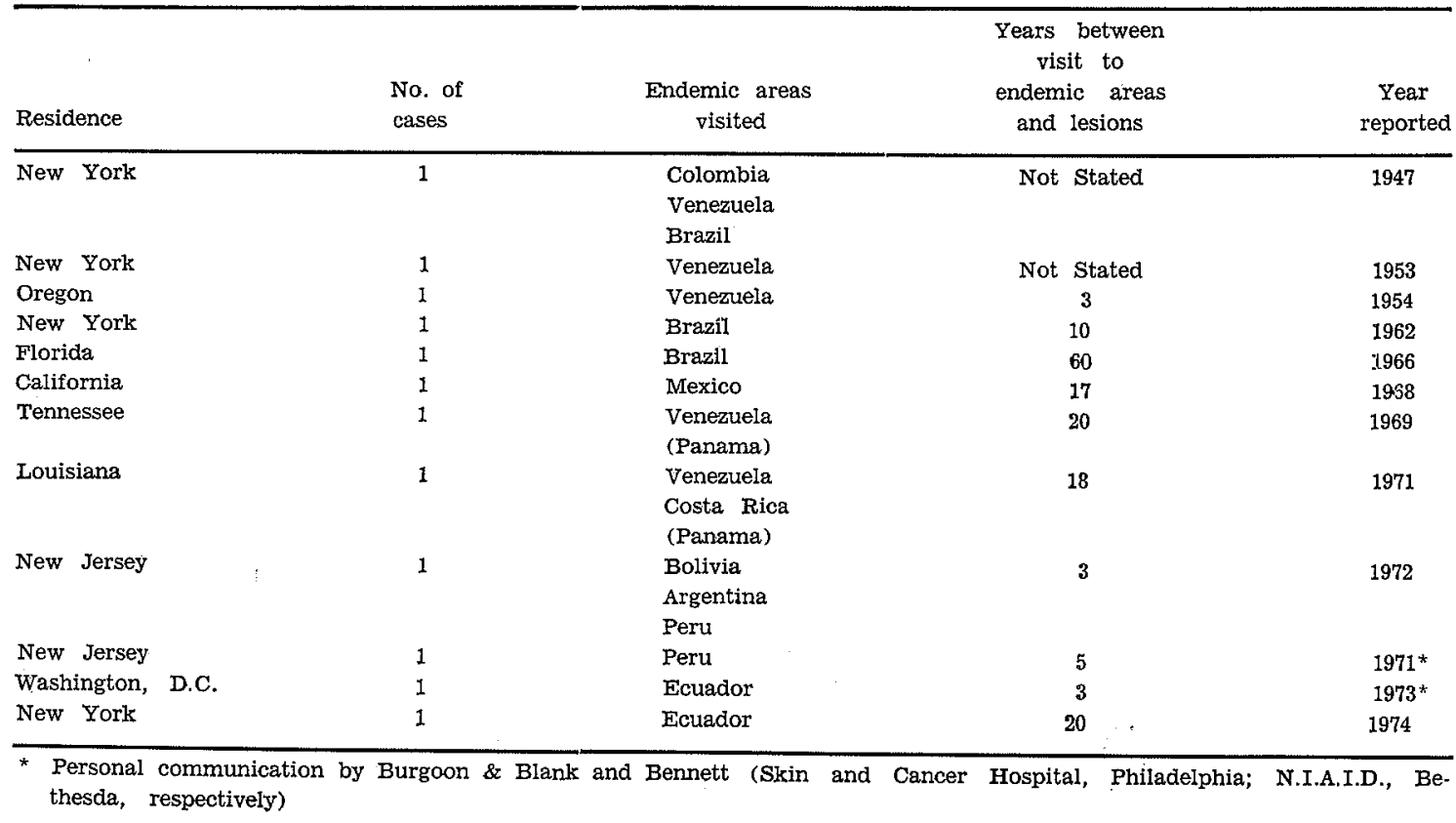

T A B L E II

Documented, nonautochthonous cases from Europe, Asia, and Africa (Greer \& Restrepo ${ }^{1},{ }^{2}$ )

\begin{tabular}{|c|c|c|c|}
\hline $\begin{array}{l}\text { Country (City) } \\
\text { where diagn. was made }\end{array}$ & $\begin{array}{l}\text { No. of } \\
\text { cases }\end{array}$ & $\begin{array}{c}\text { Endemic areas } \\
\text { visited }\end{array}$ & $\begin{array}{l}\text { Years between } \\
\text { visit to endemic } \\
\text { areas and lesions }\end{array}$ \\
\hline Spain (Madrid) & 1 & Venezuela & 10 \\
\hline Austria (Vienna) & 1 & Brazil & Not stated \\
\hline Germany (Munich) & 1 & Peru & 22 \\
\hline Italy (Genova) & 1 & Brazil & Not stafed \\
\hline Italy (Napoles) & 1 & Venezuela & 3 \\
\hline Portugal (Coimbra) & 1 & Brazil & 23 \\
\hline Portugal (unknown) & 1 & Brazil & 37 \\
\hline Portugal (Coimbra) & 1 & Brazil & 15 \\
\hline Republic of BuIgaria (Sofia) & 1 & Brazil & 30 \\
\hline Japan (Tokyo) & 1 & Brazil & 4 \\
\hline Africa (Casablanca) & 1 & Brazil & 30 \\
\hline Total & 11 & & \\
\hline
\end{tabular}

derness. Moreover, the temperature rose up till $39^{\circ} \mathrm{C}$, with the presence of lymphnodes swelling to the left side. The patient lived in São Paulo, Brazil, for nearly five years only in urban areas. At the return to Japan she visited Mexico City and Los Angeles with a stay of two to three days in each of these cities.

The patient seemed well on physical examination. Temperature was $36.5^{\circ} \mathrm{C}$, pulse 80 , respiration 24 and blood pressure $110 / 90 \mathrm{~mm} \mathrm{Hg}$.
Disseminated lymphadenopathy of cervical, axil. lar and inguinal regions was observed. The nodes diameter was nearly $2 \times 3 \mathrm{~cm}$, with smooth surface and they were movable. Heart was normal and lungs clear. Liver edge was palpable at $3 \mathrm{~cm}$ below right costal margin. Spleen tip was also palpable. Diffuse reddish erup. tion was observed on the buttock and posterior face of lower extremities. 
CHIKAMORI, T.; SAKA, S.; NAGANO, H.; SAEKI, S.; LACAZ, C. da S.; RODRIGUES, M. C.; CASSAGUERRA, C. M. \&. BRaccialli, M. L. - Puracoceidioidomycosis in Japan. Report of a case. Rev. Inst. Med. trop. São Paulo 26: $267-271,1984$,

The WBC count was 13.600 (St. 8.0, Sg. 32.0, eosino. 43.0, baso. 30 , lymph. 11.0 , mon. 2.0 , al. $0.5 \%$ ) $\mathrm{Hb} 11.7 \mathrm{~g} / \mathrm{dl}$ and platelets $39.6 \times 10.000$. ESR $125 \mathrm{~mm}$ per one hour and CRP 6+. Protein 8.9 , albumin 3.3 and gamaglobulin $3.9 \mathrm{~g} / \mathrm{dl}$. Al-p 36.4 KAU, GOT 31.0 and GPT 18.0. Bilirubin $0.4 \mathrm{mg} / \mathrm{dl}$.

In the course of the hospitalization several ether examinations were scheduled:

Chest X-ray: no active cardio-pulmonary disease, except for scoliosis.

Chest CT: subcarinal lymphnode swelling suspected.

Liver CT: marked hepatosplenomegaly, no solid mass in the liver.
Abdominal ECHO: mass of $2 \mathrm{~cm}$ in the spleen; liver intact.

Bone scinti: multiple RI high uptake area at both ribs.

Biopsy specimen of the lymphnode and liver: fungus granulomas (Fig. 1).

Cuiture of biopsied specimen: growth of Paracoccidioides brasiliensis (Fig. 2).

With the diagnosis of paracoccidioidomycosis we have received the serum of the patient, then in treatment, in June 1, 1983, for the performance of serological tests. The results obtained have agreed with the histopathological diagnosis (see serological results). Nearly five months after, a new sample of the patient's se-

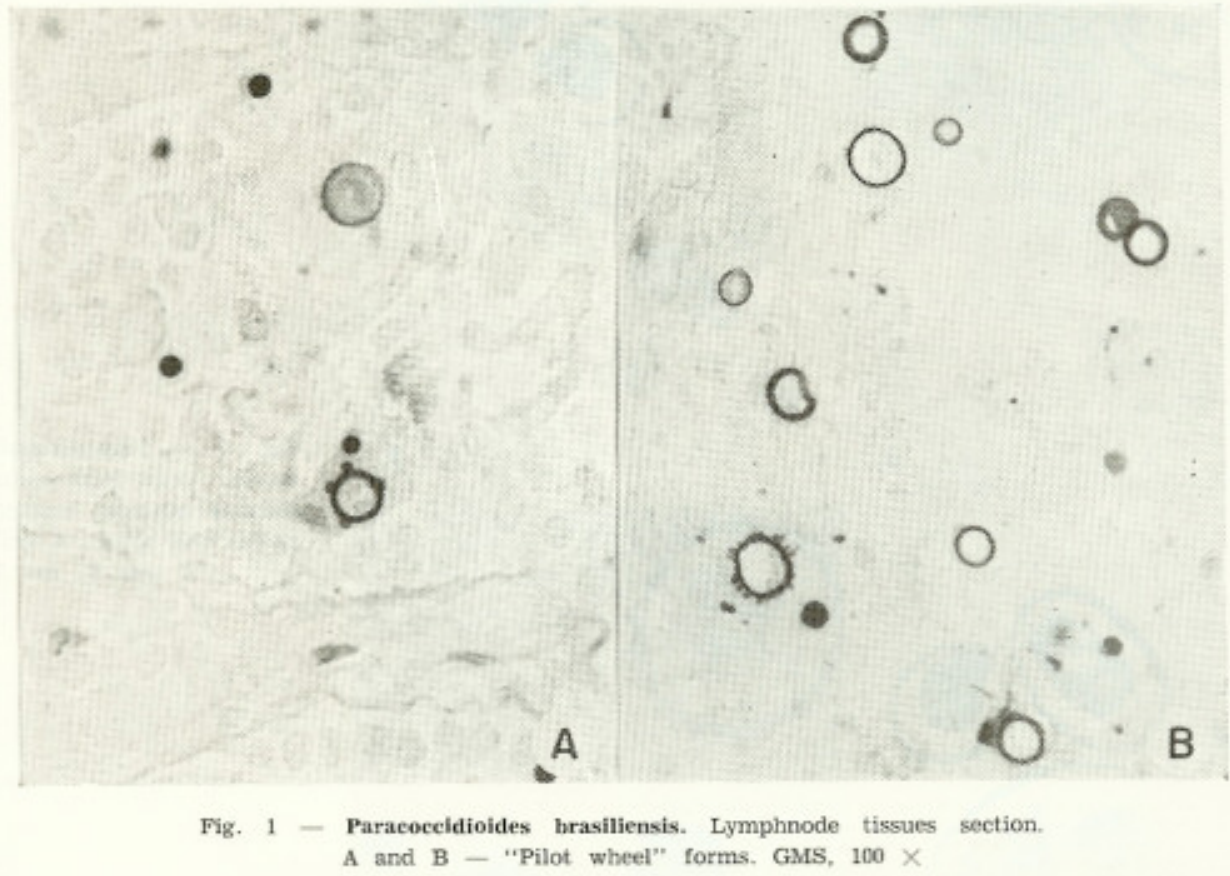

rum showed negative results by the mentioned serological tests, following the favourable clinical evolution.

After the first results, daily treatment with ketoconazole $200 \mathrm{mg}$ and amphotericin B was started. Fever fell down gradually, lymphnode swelling disappeared but C-reactive protein was still 2+. Treatment continued and ketoconazole was increased to $400 \mathrm{mg}$ daily. Other laboratory data come under normal range. No skin rash was seen. The patient's general condition was good unless for the hypokalemia, probably due to amphotericin B.

The skin test with paracoccidioidin (peptide-polysaccharide antigen) was positive; an induration of $21 \times 21 \mathrm{~mm}$ after 24 hours and $14 \mathrm{x}$ $17 \mathrm{~mm}$ after 48 hours was noted.

In November 19, 1983, the patient seemed nearly completely well. Ketoconazole $400 \mathrm{mg}$ 
CHIKAMORI, T.; SAKA, S.; NAGANO, H.; SAEKI, S.; LACAZ, C. đa S.; RODRIGUES, M. C.; CASSAGURRRA, C. M. \& BRACCialli, M. L. - Paracocciơioidomycosis in Japan. Report of a case, Rev. Inst. Med. trop. Sāo Paulo 26: $267 \cdot 271,1984$.

SEROLOGICAL RESULTS

Case of paracoccidioidomycosis in Japan. Serological tests with Paracoccidioides brasiliensis antigens (*)

\begin{tabular}{lccc}
\hline \multirow{2}{*}{ Tests } & \multicolumn{2}{c}{ Results } \\
\cline { 3 - 4 } & & 1.6 .83 & 25.11 .83 \\
\hline I.D. & & + & - \\
CIE & & - & - \\
CF & $\left\{\begin{array}{lll}\text { macro } \\
\text { Tube pp }\end{array}\right.$ & 2.5 & $1: 8$ \\
\hline
\end{tabular}

(*) Serological tests were negative with antigens of $\mathbf{H}$. capsalatum, A. fumigatus and C. albieans daily will continue for six months. ESR fell to $10 \mathrm{~mm}$ per one hour and CRP was negative. Temperature was nearly $36.6^{\circ} \mathrm{C}$.

To our request, Dr. Giovanni Guido Cerri from the Radiology Department of the School of Medicine of Săo Paulo has examined the $\mathrm{X}$-ray, CT and scintigraphy performed in Tokyo, namely:

Chest $\mathbf{X}$-ray: normal bone texture, normal transparence of lung parenchyma.

Conclusion: normal chest,

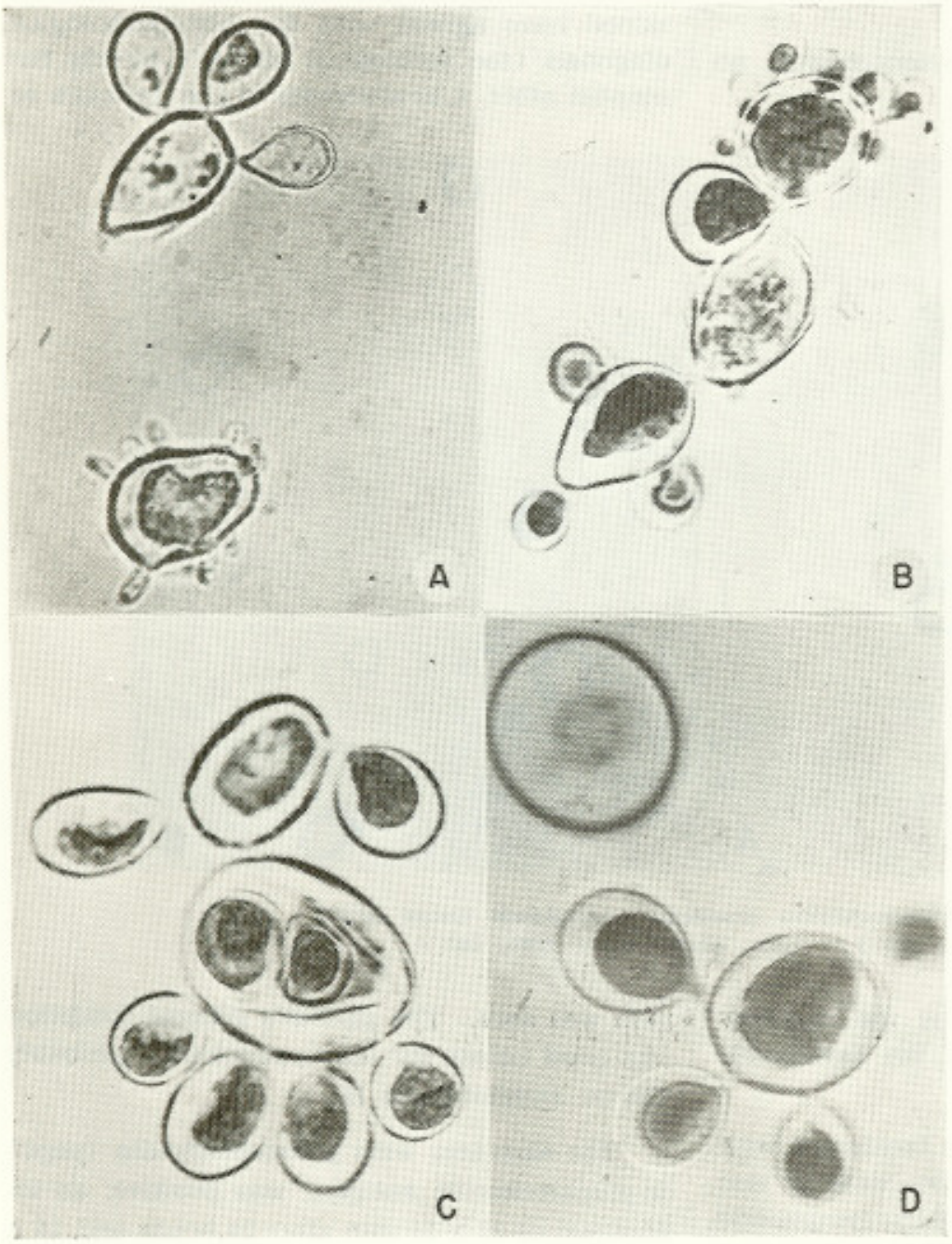

Fig, 2 - Paracoccidioides brasiliensis. Yeast form culture at $37{ }^{\circ} \mathrm{C}$ showing multiple budding. Lactophenol blue stain. $A$ and $B, 250 \mathrm{X}$ C and $\mathrm{D}, 630 \mathrm{X}$

Ultrasonography: Liver with good texture, extensive periaortic and hepatic lymphadenopathy with voluminous lymphnodes.
Chest CT: no lesions in the mediastinum and parenchyma. No marked lymphadenopathy. 
CHIKAMORI, T.; SAIKA, S.; NAGANO, H.; SAHKI, S.; LACAZ, C. da S.; RODRIGUES, M. C.; CASSAGUERRA, C. M. \& BRACCIALLI, M. L. - Paracoccidioidomycosis in Japan. Report of a case. Rev. Inst. Med. trop. São Paulo 26: $267-271,1984$.

\begin{abstract}
Abdominal CT: periaortic lymphadenopathy; spleen with heterogenous texture, suggestive of parenchyma involvement. No lesions characteristic of liver involvement.
\end{abstract}

Bone seinti: high uptake area at several ribs, with irregular borders (blastic type).

Liver scinti: liver uptake range is heterogenous. Presence of voluminous low uptake area in the region of hepatic hilus.

Conclusion: Abdominal periaortic Iymphadenopathy also present in hepatic hilus; blastic lesions in the ribs; spleen involvement.

\section{DISCUSSION}

The present case is the second reported in Japan. KOYA 3 observed in a 24-year-old Japanese farmer that lived in Brazil during four years, a case of paracoccidioidomycosis associated to visceral leishmaniasis. An intensive reticuloendothelial reaction caused by P. brasiliensis and $\mathbf{L}$. donovani was noted. The patient presented fever and hepatosplenomegaly. Cervical and mesenteric nodes swelling was observed. Blood examination showed hypochromic anemia, with leukopenia and lymphopenia. Necropsy showed I. donovani. Blastomycotic gra nuloma in the apex of left Iung were observed. That case is presented in the work of GREER \& RESTREPO ${ }^{1}$, in an excellent chapter on the epidemiology of paracoccidioidomycosis.

The present case has interesting features. During her stay in Brazil the patient has never been out of the urban zone of São Paulo where probably she acquired the primary infection. Corticoids were not used in any period of her life and no associated diseases could justify the presence of paracoccidioidomycosis. In this case 'we must emphasize the blastic aspects of bone lesions, rare in the ribs, in cases of paracoccidioidomycosis.

To explain the pathogenesis of this case we only could suppose the digestive route as entry of the parasite, since there 'were no clinical and radiological aspects of lung involvement. Her past history also did not refer any eventual data of cutaneous or mucous lesions.
Evolution was clinical and serologically favourable, with the use of two antifungal drugs, amphotericin $\mathrm{B}$ and ketoconazole.

\section{RESUMO}

Registro de um caso de paracoccidioidomicose no Japão

Os Autores descrevem um caso de paracoccidioidomicose em Tóquio, o segundo observado no Japão. A paciente residiu cerca de cinco anos na zona urbana de São Paulo, onde provavelmente adquiriu a primo-infecção. Não tomou corticóides, nem teve história de outras afecções que justificassem a paracoccidioidomicose. Após três anos do retorno ao Japão apresentou linfadenopatia, comprometimento hepatesplênico e ausência de lesões pulmonares. O presente caso, com exame histopatológico e cultivo positivos para Paracoccidioides brasiliensis também apresentou quadro sorológico compatível. O aspecto blástico das lesões ósseas, raro em arcos costais nesta micose, bem como a linfadenopatia generalizada são discutidos. Tratamento à base de anfotericina $\mathrm{B}$ e ketoconazol ofereceu resultados favoráveis. Neste trabalho os Autores discutem o problema de "patologia de importação", com suas implicações.

\section{REFERENCES}

1. GREER. D. L. \& RESTREPO, A. - The epidemiology of paracoccidioidomycosis. In Al-Doory, Y. - The Epidemiology of Human Mycotic Diseases. Springfield, C. C. Thomas, 1975, p. 117-141.

2. GREER, D. L. \& RESTREPO M., A. - La epidemiologia de la paracoccidioidomicosis. Bol, Ofic. Sanit. Panamer. 82: 428-445, 1977.

3. KOYA, G. - An autopsy case of mixed infection of Leishmania donovani and Blastomyces brasiliensis with emphasis on the histopathogenesis reticuloendotheliosis. Acta Path. Jap. 14: 223-229, 1964.

4. LACAZ, C. da S.; PORTO, E. \& MARTINS, J. E. C. Micologia Médica. São Paulo, Sarvier, 1984.

Recebicio para publicação em 8/6/1984. 